\title{
Gender Inequality In Modern India -Scenario and Solutions
}

\author{
Reshma Elizabeth Thomas \\ ${ }^{I}$ (Department of Public Administration, Anna Adarsh College for women / University of Madras, India)
}

\begin{abstract}
Gender-based inequalities in India translate into greater importance being placed on the health and empowerment of males than of females. In India, health and population indicators that are driven by gender differences include sex ratios at birth, infant and child mortality by sex, and low ages at marriage for women. At the household level, dis-empowerment of women results in less access to education, employment, and income, and power and freedom of movement. Considering all these fact, India and its society has a mammoth task of empowering women to provide them the basic needs and to prepare them for a safe and productive future.
\end{abstract}

Keywords - Women in India, Gender Inequality in India , Modern India Problems.

\section{INTRODUCTION}

Gender inequality is the question here. The reality of gender inequality in India, origin of gender inequality and how to deactivate it are discussed in this paper.

This starts with the state of gender based inequality in the modern India. It presents some facts and figures representing the inequality practiced in India and its comparison with other Asian and Western countries.

The effects of the diversified culture and differences on the inequality in general are explained first.

The origin of the inequality and the effect of modern technologies in controlling the gender in population are briefly described. The route to the present scenario is explained to show the importance and influence of the origin of the problem and India's cultural background. The different areas where the inequality is felt and problems they face in each of those areas are explained. The strategies and initiatives being done by different groups and society in general are described to show the progress happening in India to reduce the problem of gender inequality.

\section{INDIA'S PROBLEM}

India ranks 132 out of 187 countries on the gender inequality index - lower than Pakistan (123), according to the United Nations Development Program's Human Development Report 2013. The report said all countries in South Asia, with the exception of Afghanistan, were a better place for women than India, with Sri Lanka (75) topping them all. Nepal ranked 102nd and Bangladesh 111th.

Gender inequality is especially tragic not only because it excludes women from basic social opportunities, but also because it gravely imperils the life prospects of future generations. Indian families often prefer boys to girls, and female feticide is tragically common. Only $29 \%$ of Indian women above the age of 15 in 2011 were a part of the country's labor force, compared to $80.7 \%$ men. In Parliament, only $10.9 \%$ of lawmakers are women, while in Pakistan $21.1 \%$ are women. In United States which ranks 42nd on the list, $57.5 \%$ women and $70.1 \%$ men are a part of the labor force. China fared even better, landing 35th.

Only $26.6 \%$ women above 25 years received a secondary education in 2010 , compared to $50.4 \%$ of men. Pakistan scored even lower, with $18.3 \%$ of women having received secondary education compared to $43.1 \%$ of men. In the U.S., $94.7 \%$ women have received a secondary education - a figure slightly higher than for men $(94.3 \%)$. In China, this figure was $54.8 \%$ for women and $70.4 \%$ for men.

In India, 200 women died for every 100,000 childbirths, says the report. In China, the number was considerably lower (37 deaths) and in the U.S. even lower than that (21.)

\section{THE REALITY}

Firstly, the reality of gender inequality in India is very complex and diversified, because it is present in many ways, many fields and many classes. Fields like education, employment opportunities, where men are always preferred over women. Consider the case - a girl taking admission in mechanical engineering. Doesn't it sound a bit awkward because it's always considered a man's field.

The gender inequality faced by women was so much that many women claimed May God give sons to all. This is a fact and India has witnessed gender inequality from its early history due to its socio-economic and religious practices that resulted in a wide gap between the position of men and women in the society. Clearly, then gender gaps that are widespread in access to basic rights, access to and control of resources, in economic opportunities and also in power and political voice are an impediment to development. 
IV.

\section{THE ORIGIN}

Secondly, the origin of this gender inequality has always been the male dominance. At least in India, a woman still needs the anchor of a husband and a family. Their dominating nature has led women to walk with their head down. It was all practiced from the beginning and is followed till date. In the case of woman's reservation in parliament, the opposing party believes that women are born to do household work and manage kids, and not to corrupt the country by taking hold over politics. Here, just as women's domestic work is undervalued, so are their skills in the world of employment. Most are concentrated in the poorly-paid, lowskilled women's sectors of the economy.

The popular interpretations of Hindu mythology have very fixed views on how women should behave; things like being obedient and being a good housewife and mother. In the Ramayana, Ram is a model for how men should act and Sita is the model for women. Unfortunately, these play a part in perpetuating sexism and violence against women in India today.

If we focus on Hindu mythology, because $80 \%$ of Indians are Hindus and even non-Hindus are impacted by it, the religions in India view women in a similar light; they are not allowed to be independent. In some ways, these attitudes are used to justify violence against women. They blame the woman by saying she didn't behave like Sita. If she did, she would be fine.

In India, a sex-selection phenomenon has been in place since the 1980s, with men born during this period now at marriageable age. Then the urbanization since the 1990s where a lot of families and men have moved to cities to look for work. People are much wealthier but at the same time there's pressure to produce sons as an heir, so educated, wealthy families are now more likely to have sex selection. All these factors are coming to play and creating this toxic mixture, which has turned violence against women into a bigger issue today.

India's social structure is a unique blend of diverse religions, cultures and racial groups with the great religion of the world, viz, the Hindus, the Muslims, the Christians, etc, are found here. The 18 major literary languages, apart from numerous other languages and dialects adds to it. This leads to a striking diversity between various communities and groups in kinships and marriages rites, customs, inheritance and modes of living. Diversity is also seen in the pattern of rural as well as urban settlements, community life, cultural and social behaviour as also in the institutional framework.

\section{ANCIENT INDIA To PRESENT}

In the ancient India women were held in high esteem and the the position of a woman in the Vedas and the Upanishads was that of a mother (maata) or goddess (Devi). In the Manusmriti, woman was considered as a precious being and in the early Vedic age, girls were looked after with care.

Then practice of polygamy deteriorated the status of woman and in the medieval period, the practices of purdha system, dowry and sati came into being. With the passage of time, the status of woman was lowered.

After the development of science and technology, female foeticide is being practiced on a large scale. This has led to a drop in the female ratio. According to the census 2001, the sex ratio in India is 927 females to 1,000 males. And then dowry have become common and started Female infanticide practices in few areas.

In many parts of India, women are viewed as an economic liability despite contribution in several ways to our society and economy. The crime graph against women is increasing at an alarming rate. The condition of an Indian widow is quite deplorable. At home, the woman's contribution towards home as a housewife is not recognized. Domestic Violence, Rape, Sexual Exploitation, molestation, eve-teasing, forced prostitution, sexual harassment at work places etc are a common affair today and in some cases its too tragic that it gets the global attention.

The major reasons for this inequality are identified as the need of a male heir for the family, huge dowry, continued financial support to girl child, poverty, domestic violence, farming as major job for poor and the caste system.

\section{FACETS OF INEQUALITY}

At work, this disparity is visible through a different working environment for women, unequal wages, undignified treatment, sexual harassment, higher working hours, engagement in harmful industries, occupational hazards, working roughly twice as many hours as men and a nearly 27 percentage of women are accounted by unpaid activities.

Violence against women is also prominent in India which leads to every 42 minutes a sexual harassment occurring, every 43 minutes a woman kidnapped and every 93 minutes a woman is burnt for dowry. And by the pre quarter of reported, rapes involve girls under the age of 16 years. Every 26 minutes a woman is molested and every 34 minutes a rape take place. 
Poor health care is another attitude towards women which makes them neglected during illness, recognition of illness by herself, health services as a last resort and reluctance to be examined by male doctors.

Lack of education in women has lead to poor literacy leading to gender gap in literacy rate and no higher education.

Economic constraints are also imposed to women in India by keeping them as dependents, no equal property rights ( as against law ), loans of men is paid back by women, economic uncertainty and denial in inheritance of properties to orphaned / deserted.

Discriminative socialization process is another aspect of inequality towards women which leads to customary practices, more involvement in household activities only (boys not allowed), restricted to play , isolation, separation in schools and public places and restrictions to move freely.

Detrimental cultural practices like after marriage husbands dominating the family, dominance from In-laws family, members, never or rarely considered for any decision making, limitations in continuing relationships with brothers, sisters, relatives, child or early marriage, patriarchal attitudes and not able to continue girl or boy friendship after marriage are also contributing factor to the inequality.

In Governance this inequality is visible, after over sixty years of independence women are still exploited, the 73rd and 74th constitutional amendments have provided 33 percent reservation for women in the Panchayati Raj System ,Panchayat and Parliament totally 790 seats by filling 6.6-8.4 percentage, women Reservation bill delayed, cast disparity and the men domination in administration.

\section{SOCIAL ADVANCEMENT OF WOMEN}

Strategies for advancement of women should be higher literacy, more formal education, greater employment opportunity. In education it needs to be reducing primary and secondary dropout of female child. In post literacy, the basic literacy skills at speaking, reading, and writing and problem solving shall be imparted. Women learners should educate their children which further enhances social advancement.

In job opportunities there shall be reservation or expenditure or provision of services or special provisions. In governance all rights and all legal measures should be available for women's protection and support.

Human rights education, know how to take control of their circumstance, help to achieve their own goals, helping themselves, enhancing their quality of life and motivating for lobbying or advocacy are also enablers for their advancement.

Collaborators such as NGO, INGOs, NPOs, SHGs, CBOs, policy makers, local leaders, information disseminators ,health care providers, teachers and family members should help in the social advancement of women.

\section{CONCLUSION}

India need to deactivate the gender Inequality. The needs of the day are trends where girls are able not only to break out of the culturally determined patterns of employment but also to offer advice about career possibilities that look beyond the traditional list of jobs. It is surprising that in spite of so many laws, women still continue to live under stress and strain. To ensure equality of status for our women we still have miles to go.

Man and Woman are like two wheels of a carriage. The life of one without the other is incomplete.

\section{Acknowledgements}

P.SONAIMUTHU ,Executive Director, SAADOW, India, www.saadow.org, for presentation on "Gender inequality in India, the significance of being born as woman".

\section{REFERENCES}

Books:

[1] United Nations Development Program's Human Development Report 2013.

[2] “India Dishonoured: Behind a Nation's War on Women”, By Sunny Hundal, Guardian Books.

Chapters in Books:

[3] High Level Expert Group (HLEG) on Universal Health Coverage (UHC), October 2010.Chapter 9 , Gender and Health, Universal Health Coverage (UHC) Initiative Of India. 